\title{
The validity of the diabetes mellitus diagnosis in the Medical Birth Registry of Norway
}

\author{
Lars C. Stene ${ }^{1,2 *}$, Ingvild Eidem ${ }^{1,2,4^{*}}$, Siri Vangen ${ }^{1,3}$, Geir Joner ${ }^{2,4}$, \\ Lorentz M. Irgens ${ }^{5}$ and Narve Moe ${ }^{6}$ \\ ${ }^{1}$ Division of Epidemiology, Norwegian Institute of Public Health, P.O. Box 4404 Nydalen, NO-0403 Oslo, Norway \\ ${ }^{2}$ Diabetes Research Centre, Aker and Ullevål University Hospitals, NO-0407 Oslo, Norway \\ ${ }^{3}$ Department of Obstetrics and Gynaecology, Ullevål University Hospital, NO-0407 Oslo, Norway \\ ${ }^{4}$ Department of Paediatrics, Ullevål University Hospital, NO-0407 Oslo, Norway \\ ${ }^{5}$ Medical Birth Registry of Norway, Locus of Registry Based Epidemiology, Department of Public Health and \\ Primary Health care, University of Bergen and Norwegian Institute of Public Health, and University of \\ Bergen, NO-5021 Bergen, Norway \\ ${ }^{6}$ Professor emeritus, Department of Obstetrics and Gynaecology, Rikshospitalet, Oslo, Norway \\ * These authors contributed equally to this work
}

Correspondence: Lars C. Stene, Division of Epidemiology, Norwegian Institute of Public Health, P.O. Box 4404 Nydalen, NO-0403 Oslo, Norway Telephone: +4722042399 Telefax:+4722042351Ｅ-mail: lars.christian.stene@fhi.no

\begin{abstract}
The Medical Birth Registry of Norway (MBRN) has registered all births in Norway since 1967 and diabetes is registered as a maternal diagnosis. We present original data assessing the validity of the diabetes diagnosis. Among women with known pre-gestational type 1 diabetes, 97\% of births during 1976-1998 (old registration form) were identified as pre-gestational diabetes in the MBRN. For births 1999-2004 (new registration form), $94 \%$ were identified as pre-gestational diabetes in the MBRN. Of cases coded as pre-gestational diabetes by the MBRN, 80\% were confirmed by the medical record for births during 1998, while more than half of the births incorrectly coded as pre-gestational diabetes really were gestational diabetes. Among births coded as gestational diabetes, $89 \%$ were confirmed in the medical record. In conclusion, the sensitivity of the pregestational diabetes diagnosis in the Medical Birth Registry of Norway was very good, particularly in the earlier period, but the information in the MBRN on births before 1999 was not sufficient to classify pregestational diabetes as type 1 - or type 2 diabetes. The type of diabetes can be specified for births from 1999 onwards, but the predictive values are unknown. The predictive value for pre-gestational diabetes in 1998 was less than optimal but acceptable for a routine registry not specialised for diabetes.
\end{abstract}

\section{NORSK SAMMENDRAG}

Gravide kvinner med type 1 diabetes har økt risiko for komplikasjoner i svangerskapet, medfødte misdannelser og dødfødsel. Data fra medisinsk fødselsregister (MFR) har vært grunnlag for viktige publikasjoner om risiko for komplikasjoner hos gravide kvinner med diabetes. I tillegg til å gi en kort oversikt over disse publikasjonene presenterer vi data om validiteten til diabetesdiagnosen. Av fødsler til og med 1998 med kjent type 1 diabetes før svangerskapet basert på opplysninger fra Norsk diabetesregister (NDR) ble 97\% registrert som diabetes før svangerskapet i MFR (gammelt registreringsskjema). For fødsler 1999-2004, ble 94\% kodet som pre-gestasjonell (type 1- eller type 2-) diabetes. Ved sammenligning med sykehusjournalen til kvinner identifisert i MFR med diabetesdiagnose før svangerskapet (fødsler i 1998) ble diabetes før svangerskapet i følge MFR bekreftet i journalen i 80\% av tilfellene. Av fødsler kodet med svangerskapsdiabetes ble $89 \%$ bekreftet i journalen. Vi konkluderer med at sensitiviteten for pre-gestasjonell diabetes er meget god, spesielt for fødsler før 1999, men MFR kan for denne perioden ikke brukes til å klassifisere pre-gestasjonell diabetes hos mor som type 1- eller type 2 diabetes. For fødsler fra og med 1999 kan type diabetes spesifiseres, men prediktiv verdi for disse diagnosene er ikke undersøkt. Prediktiv verdi for diagnosen pre-gestasjonell diabetes i MFR for fødsler i 1998 er ikke optimal, men akseptabel for et rutineregister som ikke har diabetes som hovedfokus.

\section{INTRODUCTION}

Diabetes is a heterogeneous group of diseases defined by hyperglycaemia, caused by impaired insulin secre- tion, insulin action, or both. In addition to rare monogenic and syndromic forms, the main types are type 1, characterised by destruction of the insulin producing beta-cells in the pancreatic islets of Langerhans and 
complete dependency of insulin injections, and type 2 diabetes, characterised by a combination of insulin resistance and impaired secretion $(1,2)$. Gestational diabetes is defined as diabetes or impaired glucose tolerance recognized for the first time during pregnancy, regardless of actual time of onset and insulin dependency or treatment (1). Details of diagnostic criteria have changed over time and are beyond the scope of this paper, but interested readers are referred to the publications from the World Health Organization and the American Diabetes Association (1-4). Norwegian guidelines for diagnosis and treatment of diabetes, essentially based on the international ones, are given by The Norwegian College of General Practitioners (2005) (http://www.nsamdiabetes.no/) and by the Norwegian Society of Gynaecology and Obstetrics (2006) (http://www.legeforeningen.no/index.gan?id=40692\&s ubid $=0$ ). Gestational diabetes is a heterogeneous group of conditions. The diagnostic criteria are complex and debated, and there is no systematic study of the actual clinical practice regarding screening, "case-finding" or diagnostic criteria in Norway. Ideally, women with gestational diabetes should be reclassified after pregnancy (1), but this information is not available in the Medical Birth Registry of Norway.

Diabetes has long been recognized as a serious condition in pregnant women, with excess risk for a number of complications for mother and foetus, such as stillbirth, postnatal mortality, congenital malformations, macrosomia, preterm birth, and pre-eclampsia. Although the detailed mechanisms responsible for the different outcomes are not well known, it is clear that glycaemic control during the first six weeks of organogenesis plays an important role in minimizing the risk for congenital malformations (5). Glycaemic control later in pregnancy seems to be important for other complications in the mother and child. During the past two-three decades, improved diabetes care in pregnancy has led to greatly reduced risk for several complications. However, although it is sometimes claimed that risks for severe complications similar to that in the background population can be achieved with preconception care and intensive follow-up, this goal has not been reached in practice $(5,6)$.

Studying pregnancy outcome in women with diabetes presents a number of challenges. This includes varying criteria for and clinical practice in diagnosis, classification and detection of diabetes, varying target goals and clinical practice in treatment of women with diabetes, increasing occurrence of the different types of diabetes, and changing ethnic composition of the population. Classification of pre-gestational diabetes based on initial clinical characteristics is not always obvious, despite the recently introduced testing for antibodies to glutamic acid decarboxylase $(7,8)$. Recent studies have shown that diabetes types other than pregestational type 1 diabetes are also associated with excess risk of several complications in mother and child (9-12).

\section{THE Medical BirTh Registry OF NORWAY AND DIABETES RESEARCH}

The Medical Birth Registry of Norway (MBRN) has registered essentially all births in Norway since 1967, and diabetes is registered as a maternal diagnosis. This has been used in publications on pregnancy outcome in women with diabetes (13-16), and also studies of less well-established relations, such as those between perinatal factors and the risk of childhood onset type 1 diabetes based on registry linkage with the Norwegian Childhood Diabetes Registry (17-19), associations of type 1 diabetes associated genetic markers with size at birth $(20,21)$, and intergenerational effects of diabetes in pregnancy $(22,23)$. The first paper on pregnancy outcome in women with diabetes, by Jervell and coworkers in 1980, summarized the first years of operation of the MBRN (13), with a follow-up paper in 1994 (24). They reported that the perinatal mortality in offspring of mothers with pre-gestational diabetes fell dramatically from 1967-71 to 1987-1990. Vangen et al. included stratification by country of birth of the women (16). They reported that the overall perinatal mortality in Norwegian women with pre-gestational diabetes who gave birth during 1988-1998 was twofold higher than in those without diabetes. Perinatal mortality in offspring of immigrant women with pregestational diabetes was similar to that of Norwegian women with diabetes, although the number of births among immigrants with diabetes limited the precision of the estimated risk. There has clearly been a substantial reduction in perinatal mortality and birth defects rates in pregnancies complicated by pre-gestational diabetes from the 1970s to the 1990s. However, it is too early to conclude that the rate of severe foetal and maternal complications in women with pre-gestational diabetes is equal to that of the background population in Norway. No publication has so far included births later than 1998, and the validity of the diabetes diagnosis needs to be addressed.

In 2000, BMJ published a paper comparing perinatal mortality and risk of congenital malformations in offspring of women with and without diabetes in Norway and north-east England, based on births 19941997 (25). This paper was retracted due to a technical error invalidating the results. In stead of including women with pre-gestational diabetes only, gestational diabetes was included and erroneously reported as pregestational diabetes. The retraction attracted some attention in the clinical and research community in Norway, but the fact that corrected data as well as new data from an independent study of the positive predictive value of the pre-gestational diabetes diagnosis were published with the retraction letter (26) seems to be less widely known.

In the remainder of this paper, we describe the diabetes data available in the MBRN and present two independent sets of data assessing the validity of the diabetes diagnosis in this registry. 


\section{Coding OF DiAbetes In THE Medical BIRTH REGISTRY}

Registration and coding practice are technical and may appear boring, but are essential for understanding how to use and interpret diabetes data in the MBRN. Users of data are encouraged to inspect the registration forms used (see e.g. MBRN annual report 2003-2004).

\section{Births 1967-1998}

Until 1988, diabetes mellitus was coded in the MBRN with an ICD-8 code 250 in the variable for maternal health before pregnancy. From 1988, additions of modified ICD- 8 diabetes codes were recorded in the variable for maternal health during pregnancy, by adding an extra digit so that 2501 indicated insulintreated or type 1 diabetes, 2502 indicated diet-treated or type 2 diabetes, 2503 indicated gestational diabetes (without information about diet or insulin), and 2509 indicated diabetes where type or treatment was not specified. Due to a space limitation in the field for diagnoses before pregnancy (three digits), these fourdigit diagnoses were put in the field for maternal diagnoses during pregnancy, though they were often specifying pre-gestational diabetes. A diabetes code in the field for maternal diagnoses during pregnancy without the ICD- 8 code 250 in the field for diagnoses before pregnancy identified gestational diabetes. Note that 2501 was used whenever insulin treatment before or during pregnancy was mentioned in the registration form, also in some cases where the woman had pregestational type 2 diabetes which was treated with insulin only during the pregnancy.

Of 723 pregnancies in the MBRN during 1998 with any diabetes code, pre-gestational diabetes was coded for 274 (code 250 before pregnancy, regardless of codes assigned in the field for maternal diagnoses during pregnancy). Among these 274, 37 were simultaneously coded in the field for diagnoses during pregnancy with insulin-treated diabetes (2501), 5 were simultaneously coded with diet-treated diabetes (2502), 119 had code 2509 (not classified), 93 did not have a diabetes code during pregnancy, and finally, 20 were simultaneously coded with 2503 during pregnancy (gestational diabetes, not further specified).

The current directions of the MBRN say that all diabetes codes during pregnancy $(2501,2502,2503$, 2509) that are not accompanied by simultaneous diabetes code of 250 before pregnancy should be taken as gestational diabetes. This was the case for 449 of the 723 pregnancies. Of these 449, 298 were coded with 2503 (gestational diabetes) during pregnancy, 45 were coded with insulin-treated gestational diabetes, 95 were coded with diet-treated gestational diabetes, and 11 were coded with 2509 during pregnancy (not specified type of treatment or type of diabetes).

\section{Births 1999 to present}

Since December 1998/January 1999, a new registration form with a number of changes was introduced.
This form has pre-coded boxes for type 1 diabetes before pregnancy, type 2 diabetes before pregnancy, gestational diabetes, and for glucosuria during pregnancy, respectively. An open field is available for specification of conditions present before or during pregnancy. For births registered with the new form, ICD-10 codes are used for diagnoses. ICD-10 diabetes codes reflecting information in the open field in the form are recorded in variables specifying maternal health before pregnancy (E10, E11, E13, E14, O24.0, $\mathrm{O} 24.1, \mathrm{O} 24.3, \mathrm{O} 24.9)$ and during pregnancy (O24.4), respectively (although the ICD-10 code is not always used if the corresponding pre-coded diabetes box is ticked). In addition, a coding of insulin, A10a, has been used for maternal use of medication. According to the current directions from the MBRN, pregestational diabetes is defined when the box for type 1 - or type 2 diabetes before pregnancy is ticked, or when one of the ICD-10 codes listed above, except $\mathrm{O} 24.4$ (gestational diabetes), is registered.

In 2004, 941 pregnancies were coded with some kind of maternal diabetes or insulin treatment. Of these, 234 were coded only with pre-gestational type 1 diabetes (box in form ticked), 108 were coded only with pre-gestational type 2 diabetes, 481 were coded with gestational diabetes only, while the remaining had either single codes that were non-specific or inconsistent combinations of codes (see Appendix 1 for details).

\section{METHODS AND MATERIALS}

\section{Assessment of the positive predictive value of the diabetes diagnosis in the MBRN}

The positive predictive value (PPV) is the proportion of all cases registered with diabetes in the MBRN who truly have diabetes. This was estimated using hospital medical records as the "gold standard". The medical records for women who had diabetes before or during pregnancy according to the MBRN and gave birth during 1998 in a total of 41 hospitals all over Norway were assessed by Narve Moe and other clinicians at the birth institutions (see Appendix 3 for list of hospitals). Altogether, 723 births were registered in the MBRN in 1998 with any diabetes code. The results of the medical record review was summarised in a standardised form specifying whether the woman had diabetes diagnosed for the first time during the relevant pregnancy (gestational diabetes), or whether diabetes was present before pregnancy (pre-gestational diabetes). Type 1 or type 2 was specified if sufficient information was provided. A brief summary of the results on pre-gestational diabetes was published in the letter to the editor of the BMJ in 2003 (26). Of the 723 births registered in the $\mathrm{MBRN}$, the medical record was retrieved for 674, and the medical record was deemed conclusive by the clinician in 668 of these. Among the births where the medical record was conclusive, the MBRN had registered pre-gestational diabetes for 254 
and gestational diabetes for 414. A separate review was done of medical records from women with diabetes codes in the MBRN who gave birth at Aker hospital in Oslo or one of 11 other hospitals (see Appendix 3) who were themselves born abroad (immigrants). Information about the country of birth was extracted from the medical records.

\section{Assessment of the sensitivity of the diabetes diagnosis in the MBRN}

The sensitivity of the diabetes diagnosis (often called ascertainment) is the proportion of true cases of diabetes in the mother that are coded as diabetes in the MBRN. To assess the sensitivity for pre-gestational type 1 diabetes, we linked persons with type 1 diabetes registered in the Norwegian Childhood Diabetes Registry to the MBRN, using the diabetes registry as the "gold standard". The Norwegian Childhood Diabetes Registry has prospectively registered all cases of newly diagnosed type 1 diabetes under the age of 15 years from 1989 (27). All diagnosed cases of type 1 diabetes in childhood are referred to the paediatric department at one of the county hospitals, and one paediatrician at each of these hospitals is responsible for notification to the registry (see Appendix 2 for a list of contributors). The day of the first insulin injection is used as the day of diagnosis. In addition, Geir Joner registered retrospectively all cases of type 1 diabetes with onset below age 15 years during 1973-1982 (28), as well as all cases diagnosed between age 15 and 29 years in the period 1978-1982 (29). Among persons with type 1 diabetes described above, women with known type 1 diabetes in the diabetes registry who gave birth in this period were identified by linkage to MBRN via the 11digit personal identification number. The project was approved by the Norwegian Data Inspectorate and The Directorate for Health and Social Affairs. In the cohort of women with known pre-gestational type 1 diabetes in the Norwegian Childhood Diabetes Registry, 1025 births (by 606 mothers) were registered in the MBRN during 1976-1998, and 419 births (by 331 mothers) were registered between 1999 and 2004. The distribution of birth-years reflects the age-distribution of the women included in the diabetes registry and the years of operations, and does not represent the true occurrence of diabetes among all women who gave birth in the period covered. Ninety percent of the births occurred from 1985 and onwards, and $80 \%$ of the births occurred among women diagnosed before age 15 years.

\section{RESULTS}

\section{Sensitivity of the pre-gestational diabetes diagnosis in the MBRN}

Of births 1976-1998 among women with known pregestational type 1 diabetes, $97 \%$ were coded with pregestational diabetes in the MBRN (Table 1a). The combination of codes used for births among women with known pre-gestational type 1 diabetes during 1999-2004 is shown in Table 1b. In this period, 94\% were coded with pre-gestational diabetes according to the MBRN (first seven lines of Table 1b). Seventyeight percent were correctly and uniquely coded with pre-gestational type 1 diabetes in the MBRN (Table $1 b)$.

\section{Positive predictive value of the gestational diabetes diagnosis in the MBRN for births during 1998}

Among the 449 births coded by the MBRN as gestational diabetes, a conclusive hospital medical record was available for 414 . The gestational diabetes diagnosis was confirmed in the medical record in $89 \%$ of the cases (Table 2). About one third of the incorrectly classified births were pre-gestational diabetes according to the medical record.

\section{Positive predictive value of the pre-gestational diabe- tes diagnosis in the MBRN for births during 1998}

Among the 274 births coded by the MBRN as pregestational diabetes, a conclusive hospital medical record was available for 254. The pre-gestational diabetes diagnosis was confirmed in $79.5 \%$ (Table 3 ), while more than half of births incorrectly classified by the MBRN were gestational diabetes according to the medical record review. Of the births classified as pregestational by the MBRN, 179 were pre-gestational type 1 diabetes and 23 were pre-gestational type 2 diabetes according to the medical record review. Because the information on type or treatment in this period was not sufficient to meaningfully classify pregestational diabetes as type 1- or type 2 diabetes (see section on coding above), positive predictive values could not be presented separately for type 1- and type 2 diabetes.

\section{Medical records for immigrant mothers}

Of the 91 births during 1998 reviewed for immigrant mothers coded with diabetes, the medical record was conclusive with regard to the diabetes diagnosis in 90 . Twenty-three of these were born in Pakistan, 10 in Sri Lanka, 8 in India, 16 in Africa, 6 in the Middle East, 5 in Philippines, 5 in Vietnam, 3 in Turkey, one in Mexico, one in Chile, and 12 in Europe or the USA.

Of the 90 immigrant mothers, 67 had gestational diabetes according to the MBRN, of which 58 were confirmed by the medical record $(86.6 \%, 95 \%$ confidence interval: $78.4 \%-94.7 \%$ ). Of the 9 births incorrectly classified, 2 had pre-gestational type 2 diabetes and 7 had no mention of diabetes in the medical record.

Twenty-three immigrant women had pregestational diabetes according to the MBRN, of which 15 were confirmed in the medical record $(65.2 \%, 95 \%$ confidence interval $45.8 \%-84.7 \%$ ). Of the 15 with pregestational diabetes, 4 had type 1 diabetes and 11 had 
Table 1a. Ascertainment (sensitivity) in the Medical Birth Registry of Norway 1976-1998 of pre-gestational type 1 diabetes.

\begin{tabular}{lccc}
\hline $\begin{array}{l}\text { Pre-gestational type } 1 \text { diabetes according to } \\
\text { the Norwegian Childhood Diabetes Registry }\end{array}$ & \multicolumn{3}{c}{ Maternal diabetes diagnosis registered in the Medical Birth Registry of Norway } \\
\cline { 2 - 4 } $\mathrm{N}=1025$ & Pre-gestational diabetes & Gestational diabetes & No diabetes \\
\hline
\end{tabular}

* The $95 \%$ confidence interval for the sensitivity was $96.2 \%-98.2 \%$.

Table 1b. Diabetes diagnoses registered in the Medical Birth Registry of Norway 1999-2004 for 419 women with pre-gestational type 1 diabetes.

\begin{tabular}{lc}
\hline Pre-gestational type 1 diabetes according to the Norwegian Childhood Diabetes Registry & $\mathrm{N}=419$ \\
\hline Diagnostic codes in the Medical Birth Registry of Norway & \\
\hline Type 1 diabetes only & $325(77.6 \%)^{* \dagger}$ \\
Type 1 diabetes and gestational diabetes & $43(10.3 \%)^{* \dagger}$ \\
Unspecified diabetes (E14) before pregnancy & $8(1.9 \%) \dagger$ \\
Type 1 and type 2 diabetes & $1(0.2 \%)^{*} \dagger$ \\
Type 2 diabetes only & $14(3.3 \%) \dagger$ \\
Type 2 diabetes and gestational diabetes & $1(0.2 \%) \dagger$ \\
Unspecified diabetes (E14) during pregnancy & $1(0.2 \%) \dagger$ \\
Gestational diabetes only & $7(1.7 \%)$ \\
Insulin use during pregnancy only & $5(1.2 \%)$ \\
No code of diabetes or insulin use & $14(3.3 \%)$ \\
\hline
\end{tabular}

* MBRN type 1 diabetes: $369 / 419=88.1 \%$ (95\% confidence interval $85.0 \%-91.2 \%)$

$\dagger$ MBRN pre-gestational diabetes: 393/419=93.6\% (95\% confidence interval 91.5\%-96.1\%)

Table 2. Positive predictive value of a diagnosis of gestational diabetes in the Medical Birth Registry of Norway in 1998, on the basis of medical record review.

\begin{tabular}{|c|c|c|c|}
\hline \multirow[b]{2}{*}{ Medical Birth Registry } & \multicolumn{3}{|c|}{ Medical record review } \\
\hline & Gestational diabetes & Pre-gestational diabetes & No diabetes \\
\hline Gestational diabetes $(n=414)$ & $370(89.4 \%)^{*}$ & $16(3.9 \%) \dagger$ & $28(6.8 \%)$ \\
\hline
\end{tabular}

Table 3. Positive predictive value of a diagnosis of pre-gestational diabetes in the Medical Birth Registry of Norway in 1998 , on the basis of medical record review.

\begin{tabular}{lccc}
\hline & \multicolumn{3}{c}{ Medical record review } \\
\cline { 2 - 4 } Medical Birth Registry & Pre-gestational diabetes & Gestational diabetes & No diabetes \\
\hline Pre-gestational diabetes $(\mathrm{n}=254)$ & $202(79.5 \%)$ & $32(12.6 \%)$ & $20(7.9 \%)$ \\
\hline * The $95 \%$ confidence interval for the positive predictive value of the pre-gestational diabetes diagnosis in the Medical \\
Birth Registry of Norway (MBRN) was $74.6 \%-84.5 \%$. Of the births classified by the MBRN as pre-gestational, 179 \\
were pre-gestational type 1 diabetes and 23 were pre-gestational type 2 diabetes according to the medical record review.
\end{tabular}

type 2 diabetes according to the medical record. Among the 8 births incorrectly classified, 6 were gestational diabetes and for 2 there was no mention of diabetes in the medical record.

\section{Assessment of coding errors}

To get an impression of how the diabetes information written on the registration form is coded, and whether the written information is clearly interpretable, one of us (IE) reviewed a random sample of 100 registration forms from 1998 with accompanying codes for diabetes. All hundred cases had some kind of diabetes information written in the form by the midwife or gynecologist. One case had a clear coding error, where gestational diabetes was coded as pregestational diabetes. Five cases had information about gestational diabetes in a previous pregnancy, of which three were coded with the ICD- 8 code 250 for maternal health 
before pregnancy (the other two were not coded with 250 before pregnancy, but were included in this review due to gestational diabetes in the current pregnancy). Two other cases had forms that were difficult to interpret, including one case where the only written information about diabetes was "diabetes matris" in the field for the baby's health, meaning that the baby was influenced by diabetes in the mother. In this case the mother was coded with unspecific diabetes during pregnancy (2509). In the other case "diabetes in the mother" in the space for conditions in the family (without clearly specifying whether this pertained to the birth giving woman or her mother) was interpreted as pre-gestational diabetes (code 250).

\section{Discussion}

We have provided novel information on the validity of the diabetes diagnosis in the Medical Birth Registry of Norway (MBRN). Other important aspects such as complications associated with maternal diabetes, mechanisms behind the specific complications, screening for and treatment of maternal diabetes are all beyond the scope of this paper. Pregnancy outcome of births by women identified with pre-gestational type 1 diabetes by linkage of the Medical Birth Registry of Norway with the Norwegian Childhood Diabetes Registry will be presented elsewhere in the future.

\section{Strengths and limitations}

The assessment of the sensitivity for pre-gestational diabetes in the mother was established by registry linkage to a nation-wide diabetes registry (28-30). This was limited to type 1 diabetes with onset before age 15 in the majority of cases. A separate analysis of women diagnosed at age 15-29 indicated that the sensitivity was similar regardless of age at onset of pregestational type 1 diabetes (data not shown). Data were not available for validation of the sensitivity for pre-gestational type 2 diabetes. Another strength of the study was that an informative medical record was identified in the large majority of births coded with diabetes in the MBRN during one year, with essentially all birth institutions in Norway represented. However, the study of predictive value is limited by the quality of the information on diabetes in the medical record and by the fact that type 2 diabetes is underdiagnosed in the population $(31,32)$. Medical records are likely to be less informative for the "mild" forms of gestational diabetes that are recommended to be treated by diet. Unfortunately, we have no data on the predictive value of the diabetes diagnosis in the MBRN for births after the introduction of a new registration form in 1999. The changes in the new registration form are likely to have influenced the validity to some extent, although this is currently not known. The prevalence of pre-gestational diabetes registered in the MBRN has increased in recent years.
This may as a whole reflect a true increase in the prevalence of diabetes among women giving birth. However, it is important in the future to study the predictive value of the diabetes diagnoses in the MBRN for births from 1999 and later.

Although we found a high ascertainment of type 1 diabetes in the MBRN, the estimated prevalence of pre-gestational diabetes in the MBRN during the 1990s (around 0.3-0.4\%) is lower than the estimated prevalence of type 1 diabetes at age 30 years in the population (about $0.6 \%$, based on the incidence $0-14$ years in the 1990s (27), and the incidence 15-29 years during 1978-82 (29) in the Norwegian Childhood Diabetes Registry, and assuming negligible mortality). These data are not directly comparable, but the difference could be explained by a lower fertility rate among women with type 1 diabetes. This will be investigated and reported in a future study.

\section{Types of misclassification}

Of the births incorrectly coded with pre-gestational diabetes in the MBRN, a considerable proportion had gestational diabetes in the medical record, and vice versa. Evaluation of the coding practice revealed that "pure" coding errors were very rare. In 3 of 100 forms reviewed, notification of gestational diabetes in a previous pregnancy was coded with ICD- 8 code 250 before pregnancy. Since there was no coding scheme to specify this scenario in the old registration form, the choice to use the diabetes code here may be regarded as technically correct, but it is inappropriate for most applications.

Furthermore, medical records sometimes only contained results of oral glucose tolerance test, without further information about symptoms and repeat testing. With changing and confusing diagnostic criteria, a certain proportion of errors (or lack of information) in both medical records and birth registration forms is probably inevitable.

\section{Comparison with other studies}

Detailed clinical information on each pregnancy should ideally have been available for studies of the outcome of pregnancy in women with diabetes, but given the relative rarity of both pre-gestational type 1 diabetes and the serious complications such as perinatal mortality and malformations, clinical studies are frequently too small, and one has to base studies on existing registries which often lack high-quality data on type of diabetes and metabolic control during pregnancy. Many such studies have been reported, see e.g. refs. $(9,33,34)$ for recent publications, but few have validated the diabetes diagnoses adequately. In Sweden, women with maternal diabetes have been identified by record linkage to the Inpatient Registry, which is not complete and does not contain appropriate data on the type of pre-gestational diabetes $(9,35)$. Their results for births in the 1980 s indicated relative risks 
slightly higher than those found in the MBRN (35). The validation of the Swedish Medical Birth Registry reported in 1990 (36) did not include an independent evaluation of the maternal diabetes diagnosis, but a more recent study has evaluated 184 medical records from women coded with gestational diabetes in the birth registry. They reported that $96.7 \%$ were correct (9), a figure slightly higher than what we have found for the MBRN.

\section{Impact of misclassification}

The impact of misclassification depends on the type and magnitude of misclassification, and on the intended use of the data. For instance, the observed results indicate that estimates of prevalence of diabetes is likely to be incorrect, but if the aim is to remove from analysis all of the births where the mother had pregestational type 1 diabetes, the data are probably suitable for the purpose. The positive predictive value of the pre-gestational diagnosis was moderate, and perhaps lower than could have been expected. On the other hand, as demonstrated by Hawthorne et al. (26), a misclassification in $20 \%$ of the cases would lead to a modest deflation of the relative risk for perinatal mortality and malformations. The observed perinatal mortality for Norway in the period 1994-1997 reported by Hawthorne et al. (26) was 7.2 per 1000 births among women registered without maternal diabetes and 15.6 per 1000 for mothers with pre-gestational diabetes, giving a relative risk of 2.17 . The observed perinatal mortality rate of 15.6 for those coded with pregestational diabetes in the MBRN can be expressed as a weighted mean of the rate among the $20 \%$ incorrectly coded (assumed to be equal to that in the background population) and the unknown rate $\mathrm{X}$ among the $80 \%$ correctly coded births as follows: $0.8 \cdot \mathrm{X}+0.2 \cdot 7.2$ $=15.6$. By simple algebra, we can work out that the unobserved rate among those with true pre-gestational diabetes under this scenario is 17.7 per 1000 , corresponding to a relative risk of 2.46. Similar calculations by Hawthorne et al. showed that the relative risk for congenital malformations for women with pregestational diabetes was inflated from 1.3 to 1.4 by the misclassification. Similar calculations could also be done for the impact of non-complete ascertainment. With a prevalence of pre-gestational diabetes less than $1 \%$, a non-complete ascertainment would not influence these relative rates.

\section{CONCLUSION}

In conclusion, we have demonstrated a very good ascertainment of pre-gestational diabetes in the MBRN among women with type 1 diabetes. The new registration form introduced in 1999 allowed for specification of type of pre-gestational diabetes, but the predictive values of diabetes diagnoses are not known. For births during 1998 coded as pre-gestational diabetes and gestational diabetes according to the MBRN, approximately $80 \%$ and $90 \%$ were confirmed by medical records, respectively.

\section{ACKNOWLEDGEMENT}

Ingvild Eidem and Geir Joner were supported by a Ph.D.grant from Eastern Norway Regional Health Authority (Ullevål University Hospital Trust). The authors would like to thank clinicians at all the birth institutions (listed in Appendix 3) involved in the review of medical records for invaluable help. Thanks also to Grace Egeland, Rolv Terje Lie, Jak Jervell, Sachiko Watanabe, and the staff at the Medical Birth Registry of Norway for assistance with various aspects of this study.

\section{CONTRIBUTORS}

NM contributed to the planning of the medical record review together with LMI, SV, and others. NM and other clinicians at the hospitals listed in Appendix 3 reviewed medical records retrieved from lists created by the MBRN (LMI). LMI summarized the conclusions based on medical review and assigned this information to the appropriate birth in the MBRN. Sachiko Watanabe punched this information into a database. SV reviewed medical records from immigrant mothers. GJ is the principal investigator for the project based on linkage of the Medical Birth Registry and the Norwegian Childhood Diabetes Registry. IE analysed the linked data and reviewed registration forms for coding errors, and drafted several text sections. LCS analysed the computerised data based on medical record review linked to the diabetes codes in the MBRN, and drafted the manuscript with input from all authors.

\section{REFERENCES}

1. WHO. Definition, diagnosis and classification of diabetes mellitus and its complications: report of a WHO consultation. Part 1: Diagnosis and classification of diabetes mellitus. Geneva: World Health Organization, 1999.

2. American Diabetes Association. Diagnosis and classification of diabetes mellitus. Diabetes Care 2007; 30 (Suppl 1): S42-S47.

3. The Expert Committee on the Diagnosis and Classification of Diabetes Mellitus. Report of the expert committee on the diagnosis and classification of diabetes mellitus. Diabetes Care 1997; 20: 1183-1197.

4. The Expert Committee on the Diagnosis and Classification of Diabetes Mellitus. Follow-up report on the diagnosis of diabetes mellitus. Diabetes Care 2003; 26: 3160-3167.

5. Taylor R, Davison JM. Type 1 diabetes and pregnancy. BMJ 2007; 334: 742-745. 
6. Ray JG, O'Brien TE, Chan WS. Preconception care and the risk of congenital anomalies in the offspring of women with diabetes mellitus: a meta-analysis. QJM 2001; 94: 435-444.

7. Turner R, Stratton I, Horton V, Manley S, Zimmet P, Mackay IR, et al. UKPDS 25: autoantibodies to isletcell cytoplasm and glutamic acid decarboxylase for prediction of insulin requirement in type 2 diabetes. Lancet 1997; 350: 1288-1293.

8. Arnqvist HJ, Littorin B, Nyström L, Schersten B, Östman J, Blohme G, et al. Difficulties in classifying diabetes at presentation in the young adult. Diabet Med 1993; 10: 606-613.

9. Åberg A, Westbom L. Association between maternal pre-existing or gestational diabetes and health problems in children. Acta Paediatr 2001; 90: 746-750.

10. Crowther CA, Hiller JE, Moss JR, McPhee AJ, Jeffries WS, Robinson JS. Effect of treatment of gestational diabetes mellitus on pregnancy outcomes. N Engl J Med 2005; 352: 2477-2486.

11. Macintosh MC, Fleming KM, Bailey JA, Doyle P, Modder J, Acolet D, et al. Perinatal mortality and congenital anomalies in babies of women with type 1 or type 2 diabetes in England, Wales, and Northern Ireland: population based study. BMJ 2006; 333: 177.

12. Lapolla A, Dalfra MG, Di Cianni G, Bonomo M, Parretti E, Mello G, et al. A multicenter Italian study on pregnancy outcome in women with diabetes. Nutr Metab Cardiovasc Dis 2007 (in press).

13. Jervell J, Bjerkedal T, Moe N. Outcome of pregnancies in diabetic mothers in Norway 1967-1976. Diabetologia 1980; 18: 131-134.

14. Lie RT, Irgens LM, Skjærven R, Bergsjø P. Secular changes in early neonatal mortality in Norway, 19671981. Am J Epidemiol 1987; 125: 1066-1078.

15. Hellesen HB, Vikane E, Lie RT, Irgens LM. Maternal diabetes - normalized perinatal mortality, but still high fetal growth [In Norwegian]. Tidsskr Nor Lageforen 1996; 116: 3465-3469.

16. Vangen S, Stoltenberg C, Holan S, Moe N, Magnus P, Harris JR, et al. Outcome of pregnancy among immigrant women with diabetes. Diabetes Care 2003; 26: 327-332.

17. Stene LC, Magnus P, Lie RT, Søvik O, Joner G, the Norwegian Childhood Diabetes Study Group. Birth weight and childhood onset type 1 diabetes: population based cohort study. BMJ 2001; 322: 889-892.

18. Stene LC, Magnus P, Lie RT, Søvik O, Joner G, the Norwegian Childhood Diabetes Study Group. Maternal and paternal age at delivery, birth order, and risk of childhood onset type 1 diabetes: population based cohort study. BMJ 2001; 323: 369-371.

19. Stene LC, Magnus P, Lie RT, Søvik O, Joner G, the Norwegian Childhood Diabetes Study Group. No association between pre-eclampsia or cesarean section and incidence of type 1 diabetes among children: a large population based cohort study. Pediatr Res 2003; 54: 487-490.

20. Stene LC, Magnus P, Rønningen KS, Joner G. Diabetes-associated HLA-DQ genes and birth weight. Diabetes 2001; 50: 2879-2882.

21. Stene LC, Thorsby PM, Berg JP, Rønningen KS, Undlien DE, Joner G, et al. The relation between size at birth and risk of type 1 diabetes is not influenced by adjustment for the insulin gene (-23HphI) polymorphism or HLA-DQ genotype. Diabetologia 2006; 49: 2068-2073.

22. Egeland GM, Skjaerven R, Irgens LM. Birth characteristics of women who develop gestational diabetes: population based study. BMJ 2000; 321: 546-547.

23. Egeland GM, Skjaeven R, Irgens L. The reproductive health of daughters of pregestational diabetic women: Medical Birth Registry of Norway. Paediatr Perinat Epidemiol 2002; 16: 290-296.

24. Jervell J, Magnus P, Moe N, Bakketeig LS, Halse J. Resultatet av svangerskap hos diabetikere: utviklingen i Norge fra 1967 til 1990. Nor J Epidemiol 1994; 4: 34-35.

25. Hawthorne G, Irgens LM, Lie RT. Outcome of pregnancy in diabetic women in northeast England and in Norway, 1994-7. BMJ 2000; 321: 730-731.

26. Hawthorne G, Irgens LM, Lie RT, Moe N, Jervell J. Retraction of paper on maternal diabetes. BMJ 2003; 327: 929.

27. Aamodt G, Stene LC, Njølstad PR, Søvik O, Joner G, the Norwegian Childhood Diabetes Study Group. Spatiotemporal trends and age-period-cohort modeling of the incidence of type 1 diabetes among children aged $<15$ years in Norway 1973-1982 and 1989-2003. Diabetes Care 2007; 30: 884-889.

28. Joner G, Søvik O. Increasing incidence of diabetes mellitus in Norwegian children 0-14 years of age 19731982. Diabetologia 1989; 32: 79-83.

29. Joner G, Søvik O. The incidence of type 1 (insulin-dependent) diabetes mellitus 15-29 years in Norway 19781982. Diabetologia 1991; 34: 271-274.

30. Joner G, Stene LC, Søvik O, the Norwegian Childhood Diabetes Study Group. Nationwide, prospective registration of type 1 diabetes in children aged < 15 years in Norway 1989-1998: No increase but significant regional variation in incidence. Diabetes Care 2004; 27: 1618-1622.

31. Stene LC, Midthjell K, Jenum AK, Skeie S, Birkeland KI, Lund E, et al. Hvor mange har diabetes mellitus i Norge? Tidsskr Nor Lageforen 2004; 124: 1511-1514. 
32. The DECODE Study Group. Age- and sex-specific prevalences of diabetes and impaired glucose regulation in 13 European cohorts. Diabetes Care 2003; 26: 61-69.

33. Nielsen GL, Norgard B, Puho E, Rothman KJ, Sorensen HT, Czeizel AE. Risk of specific congenital abnormalities in offspring of women with diabetes. Diabet Med 2005; 22: 693-696.

34. Sharpe PB, Chan A, Haan EA, Hiller JE. Maternal diabetes and congenital anomalies in South Australia 1986-2000: a population-based cohort study. Birth Defects Res A Clin Mol Teratol 2005; 73: 605-611.

35. Cnattingius S, Berne C, Nordstrom ML. Pregnancy outcome and infant mortality in diabetic patients in Sweden. Diabet Med 1994; 11: 696-700.

36. Cnattingius S, Ericson A, Gunnarskog J, Källén B. A quality study of a medical birth registry. Scand J Soc Med 1990; 18: 143-148.

Appendix 1. Combinations of diabetes or insulin codes used for births registered in the Medical Birth Registry of Norway during 2004.

\begin{tabular}{lr}
\hline Any diabetes or insulin code & $\mathrm{N}=941$ \\
\hline Type 1 diabetes only & $234 \ddagger$ \\
Unspecified diabetes (E14) before pregnancy & $13 \ddagger$ \\
Type 1 and type 2 diabetes & $4 \ddagger$ \\
Type 2 diabetes only* & $108 \ddagger$ \\
Type 1 diabetes and gestational diabetes & $48 \ddagger$ \\
Type 2 diabetes and gestational diabetes & $35 \ddagger$ \\
Unspecified diabetes (E14) during pregnancy & $2 \ddagger$ \\
Gestational diabetes only & $481 \S$ \\
Insulin use during pregnancy only & 7 \\
Gestational diabetes (O24.4) in a previous pregnancy only $\dagger$ & 9 \\
\hline
\end{tabular}

* Three of these were coded with the ICD-10 code E11 before pregnancy, the rest were only ticked for type 2 diabetes in the pre-coded box on the registration form.

$\dagger$ ICD-10 code O24.4 in mother's health before pregnancy. We assume that these cases represent gestational diabetes in a previous pregnancy. In total, 12 cases had such a code before pregnancy, three of them in combination with other diabetes codes.

\$ A total of 444 cases are counted as pre-gestational diabetes according to the current directions of MBRN. These include the cases with a code for gestational diabetes in addition to type 1 diabetes or type 2 diabetes and the cases coded E14 during pregnancy.

$\S$ According to the directions from MBRN, these 481 are the total number of cases to be taken as gestational diabetes. Fifteen were coded with the ICD-10 code O24.4 during pregnancy, the rest were ticked for gestational diabetes in the pre-coded box on the registration form.

Appendix 2. Contributors to the Norwegian Childhood Diabetes Registry (Members of the Norwegian Childhood Diabetes Study Group).

Henning Aabech and Sven Simonsen, Fredrikstad; Helge Vogt, Lørenskog; Kolbeinn Gudmundsson, Anne Grethe Myhre, Knut Dahl-Jørgensen and Geir Joner, Oslo; Jon Grøtta, Elverum; Ola Tallerås and Dag Helge Frøisland, Lillehammer; Halvor Bævre, Gjøvik; Kjell Stensvold, Drammen; Bjørn Halvorsen, Tønsberg; Kristin Hodnekvam, Skien; Ole Kr. Danielsen, Arendal; Jorunn Ulriksen and Unni Mette Köpp, Kristiansand; Jon Bland, Stavanger; Dag Roness, Haugesund; Oddmund Søvik and Pål R. Njølstad, Bergen; Per Helge Kvistad, Førde; Steinar Spangen, Ålesund; Per Erik Hæreid, Trondheim; Sigurd Børsting, Levanger; Dag Veimo, Bodø; Harald Dramsdahl, Harstad; Bård Forsdahl, Tromsø; Kersti Elisabeth Thodenius and Ane Kokkvoll, Hammerfest. 
Appendix 3. Births during 1998 registered with a diabetes code before or during pregnancy in the Medical Birth Registry of Norway (MBRN), by birth institution.

\begin{tabular}{|c|c|c|}
\hline Hospital* & $\begin{array}{c}\text { Births in } 1998 \text { registered with } \\
\text { diabetes in the MBRN }\end{array}$ & $\begin{array}{l}\text { Medical record } \\
\text { retrieved }\end{array}$ \\
\hline Østfold sentralsykehus $\dagger$ & 30 & 28 \\
\hline Bærum sykehus $\dagger$ & 10 & 9 \\
\hline Sentralsykehuset i Akershus $\dagger$ & 29 & 25 \\
\hline Rikshospitalet $\dagger$ & 41 & 34 \\
\hline Ullevål sykehus† & 12 & 12 \\
\hline Aker sykehus $\dagger$ & 107 & 106 \\
\hline Hamar sykehus & 3 & 0 \\
\hline Hedmark sentralsykehus & 10 & 0 \\
\hline Gjøvik fylkessykehus & 2 & 2 \\
\hline Lillehammer fylkessykehus & 10 & 9 \\
\hline Ringerike sykehus & 1 & 1 \\
\hline Buskerud sentralsykehus $\dagger$ & 27 & 26 \\
\hline Kongsberg sykehus & 1 & 0 \\
\hline Vestfold sentralsykehus & 15 & 15 \\
\hline Telemark sentralsjukehus & 21 & 21 \\
\hline Aust-Agder sentralsjukehus & 13 & 13 \\
\hline Flekkefjord sykehus & 1 & 1 \\
\hline Vest-Agder sentralsykehus $\dagger$ & 14 & 14 \\
\hline Fylkessjukehuset i Haugesund & 25 & 25 \\
\hline Sentralsjukehuset i Rogaland $\dagger$ & 60 & 59 \\
\hline Fylkesjukehuset på Voss & 1 & 1 \\
\hline Fylkesjukehuset på Stord & 6 & 0 \\
\hline Fylkesjukehuset i Odda & 1 & 1 \\
\hline Haukeland sykehus & 132 & 127 \\
\hline Fylkesjukehuset på Nordfjordeid & 2 & 2 \\
\hline Fylkesjukehuset i Lærdal & 1 & 1 \\
\hline Sentralsjukehuset i Sogn og Fjordane & 15 & 14 \\
\hline Fylkesjukehuset i Molde & 6 & 6 \\
\hline Fylkesjukehuset i Volda & 5 & 5 \\
\hline Sentralsjukehuset i Møre og & & 49 \\
\hline Romsdal & 50 & \\
\hline Fylkesjukehuset i Kristiansund & 2 & 2 \\
\hline Orkdal Sanitetsforenings sjukehus & 1 & 0 \\
\hline Regionsykehuset i Trondheim $\dagger$ & 35 & 34 \\
\hline Innherred sykehus & 3 & 3 \\
\hline Rana sykehus & 1 & 0 \\
\hline Nordland sentralsykehus, Bodø & 8 & 8 \\
\hline Stokmarknes sykehus & 1 & 1 \\
\hline Regionsykehuset i Tromsø† & 12 & 12 \\
\hline Kirkenes sykehus & 3 & 3 \\
\hline Hammerfest sykehus $\dagger$ & 3 & 3 \\
\hline Alta Helsesenter & 3 & 2 \\
\hline Total & 723 & 674 \\
\hline
\end{tabular}

* Among a total of 41 hospitals, at least one medical record was retrieved from 35 hospitals. Narve Moe reviewed medical records at Østfold, Bærum, Akershus, Rikshospitalet, Ullevål, Aker (together with Siri Vangen), and Buskerud hospitals. Ole Jacob Nakling reviwed records at Lillehammer, Lars Johansen at Vestfold, Thyra Giæver at Telemark, Arild Kloster-Jenssen at Aust-Agder, Aud Askvold at Vest-Agder, Eli Smedvik at Rogaland, Torunn Eikeland at Haugesund, Svein Rasmussen at Haukeland, Bjørg Ladehaug at Sogn og Fjordane, Sissel Hjelle at Møre og Romsdal, Bjørn Bache at Trondheim and Martin Grønberg at Tromsø.

$\dagger$ Hospitals included in separate review of immigrant mothers. Fifty-eight of 91 immigrant women from these 12 hospitals gave birth at Aker sykehus in Oslo. 